\title{
14 Years of Progress: Canadian Undergraduate Conference on Healthcare
}

Kiera Liblik [1]*, Jennifer S. Williams [2]*

[1] CUCOH Chair 2017, Publications Coordinator 2016, Research Volunteer 2015

[2] CUCOH Research Coordinator 2017, Co-Chair 2015, Logistics Coordinator 2013, 2014

*Corresponding Authors: 14k13@queensu.ca and jenny.williams@queensu.ca

\section{Introduction}

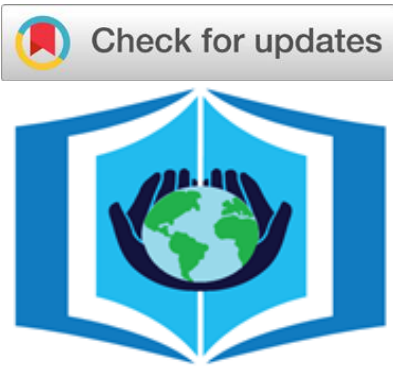

URNCST Journal

"Research in Earnest"

The Canadian Undergraduate Conference on Healthcare (CUCOH) has grown in its size and breadth of conference activities over the past 13 years, to become the largest undergraduate healthcare conference in Canada, which. It began at Queen's University, in Kingston Ontario, with a clear need to bring together undergraduate students from diverse educational backgrounds to create a forum for healthcare knowledge exchange between experts in their fields and undergraduate students. The conference quickly grew in its programming to now host innovative training workshops, expert-led case challenges, and an expanding research competition program. It also grew in its size of students and experts, now welcoming over 400 students across 8 provinces in Canada, and over 50 experts to lead workshops, seminars, and judging of the research competition.

Over the next few sections, we hope to provide you with an understanding of the inner workings of CUCOH, the successes garnered and challenges faced, and advice we would give to future conference planners.

Keywords: CUCOH; conference planning; research competition; keynote speakers; workshops

\section{CUCOH's Objectives:}

1. Provide an inclusive understanding of interdisciplinary Canadian healthcare with a focus on specific areas where significant progress is underway

2. Offer a platform for delegates and professionals to network, allowing for the dissemination of knowledge and an inclusive platform for well-informed discussion

3. Create a multidisciplinary platform for both presenters and undergraduate students to present and discuss their research

4. Provide a unique environment where discussion on diversity in healthcare is celebrated and dialogue about improving it is promoted

5. Contribute to the professional development of an innovative group of future leaders in Canadian healthcare; to leave the conference better equipped to transform to their global community

\section{Structure of CUCOH's Leadership (Figure 1)}

$\mathrm{CUCOH}$ is a multi-component conference boasting delegates from over 20 universities across Canada. Due to the far reach of this conference and commitment to exceeding the expectations of each delegate, a team of individuals is hired annually that are both motivated independently and are strong collaborators. While slight variation exists in the number of executive members from year to year, the specific sub-committees and their duties are consistent. Now in its $14^{\text {th }}$ year, $\mathrm{CUCOH}$ has seen several chairs and co-chairs head the conference team. The decision of the exiting chair/co-chairs to hire a single person or pair to take over the position depends heavily on who has applied and their level of performance collaboratively and independently during the preceding year. The executive team is hired by the incoming chair/co-chairs and consists of several smaller sub-committees and some individual positions.

Sub-Committees: Speakers (6), Research (4), Logistics (2), Marketing (2) \& Photography (1), Publications (2), External (3), Social (2), Sponsorship (2)

The largest sub-committees are the Speakers and Research committees. The Speakers committee is broken up into Workshops, Case Competition, and Speakers each responsible for the coordination of those aspects of the conference. Overall, the Speakers committee handles 
UNDERGRADUATE RESEARCH IN NATURAL AND CLINICAL SCIENCE AND TECHNOLOGY (URNCST) JOURNAL Read more URNCST Journal articles and submit your own today at: https://www.urncst.com

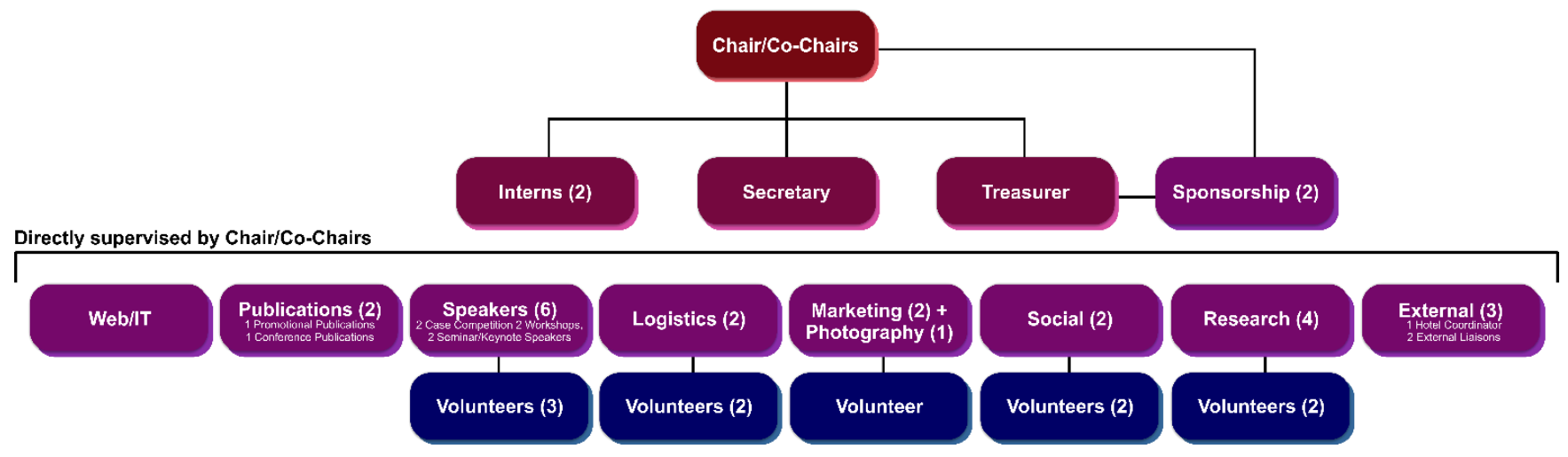

Figure 1: CUCOH Executive Structure

recruitment of presenters for seminars, key notes, workshops, case challenges and their accommodations, traveling, and confirming that their content is appropriate for the theme/audience each year.

The Research committee's duties are outlined in detail in the Research Competition section of this article, but they are responsible for reviewing all research competition applications, recruiting judges, and general research competition organization working with the Logistics committee.

Generally, the Logistics committee covers two main components of $\mathrm{CUCOH}$ planning: catering and booking. Due to the size of the conference (400+ individuals), multiple buildings and dozens of individual spaces need to be booked for an entire weekend without overlapping any other events. As well, sound systems, coat racks, tables, chairs, and other supplies need to be secured for the weekend. The Logistics committee also works closely with the Research and Speakers committees to organize the conference schedule, making sure that all delegates have access to an equal number of workshops and seminars and are fed regularly. Catering is one of the most important aspects of the delegate experience, especially due to the dozens of combinations of dietary restrictions that must be met every year.

$\mathrm{CUCOH}$ is the largest undergraduate healthcare conference in Canada, an achievement largely attributed to the continuous efforts of the Marketing, Web/IT, Publications, and Photography executives. The Marketing committee, specifically, focuses on CUCOH's social media presence and encouraging attendance to fundraising events. Throughout the year, marketing continuously posts to CUCOH's Facebook page and plans events to engage Queen's students and increase visibility on campus. Through social media campaigns and posts in Queen's and external university groups, the Marketing committee is also responsible for promoting ticket sales. Additionally, the Photography executive works closely with the Marking Committee, and is responsible for executive photos, managing the $\mathrm{CUCOH}$ Instagram, and photography/videography during the entirety of the conference weekend.

Liblik et al. | URNCST Journal (2018): Volume 2, Issue 5 DOI Link: https://doi.org/10.26685/urncst.52
Aesthetics play an important role in advertising and the Publications committee develops a visual conference identity each year that builds on CUCOH's brand and considers current marketing trends. As well, the Publications Committee develops all conference visual materials including the delegate package, sponsorship package, signs, banners, and advertisements.

The External committee plays an important role in recruiting delegates from other universities, reaching out to groups from past years and sending out recruitment e-mails to program directors at the universities themselves. As well, external ambassadors for each university group are selected before ticket sales to help recruit delegates from their universities. Once delegates have purchased their tickets, one of the External committee members takes on the job of arranging accommodations for the delegates in Kingston. Hotel booking for hundreds of people is a significant task especially when delegates have roommate preferences. The other two External executives coordinate with external ambassadors to arrange travel (delegates travel from as far as British Columbia and New Brunswick), communicate all information about conference logistics/hotel bookings, and to make sure that any special accommodations are taken care of.

The Social committee also works with venues, such as hotels, to plan for the pre-conference social as well as the $\mathrm{CUCOH}$ banquet. The pre-conference social is typically a wine and cheese either with or without the first key note, depending on speaker availability, and is either held at the conference venue or a location in downtown Kingston. The banquet is always held on the evening of the first full day of the conference (Saturday) and includes either a panel discussion or a keynote speaker for guests to listen to after dinner. The banquet is essential as it brings together all of the delegates, allowing them to share their interests, $\mathrm{CUCOH}$ experience, and gives them an opportunity to dress formally and enjoy an extravagant evening. The Social committee oversees venue booking/decoration and all dinner arrangements. This is the one catering task that does not fall under the Logistics portfolio. 
UNDERGRADUATE RESEARCH IN NATURAL AND CLINICAL SCIENCE AND TECHNOLOGY (URNCST) JOURNAL Read more URNCST Journal articles and submit your own today at: https://www.urncst.com

Finally, the Sponsorship committee works closely with the Treasurer to secure corporate and local sponsorship while applying for internal (Queen's University) and external grants.

Individual Positions: Secretary, Treasurer, Web-IT executive, Interns

Working directly with the chair/co-chairs, the secretary serves to assist with organizing meetings, responding to e-mails, volunteer hiring, and keeping track of meeting minutes. Volunteers are hired 2 months before the conference for certain sub-committees to help complete final tasks and on the day of the conference.

The treasurer works closely with the chair/co-chairs as well, keeping meticulous track of finances and ensuring that all executive members adhere strictly to their budget to secure seed money for the next year's conference. The treasurer position was introduced in the $13^{\text {th }}$ conference year, which was one of the key factors contributing to the significant increase in seed money for this upcoming conference as compared to past years.

The Web/IT executive is responsible for updating the website and keeping it consistent with the theme as well as updating CUCOH's registration and the preference system. The preference system is developed to recognize individual meal, seminar, workshop, case challenge preferences during registration and to schedule each delegate's weekend to maximize their $\mathrm{CUCOH}$ experience based on their interests. This is especially complicated given the amount of unique schedule combinations and the limitation of seminar and workshop capacities.

Finally, the interns work as liaisons between the chair/co-chairs and the sub-committees. The interns split the sub-committees between themselves and act as allpurpose volunteers for any tasks that need to be completed that the other executive members need assistance with. The interns are often first or second year undergraduate students with limited exposure to $\mathrm{CUCOH}$. The position acts to support them gain an understanding of how the conference is planned, so they may be part of the planning process for the following year. This assists the conference in maintaining long-term sustainability and engagement with early undergraduate students.

Overall, CUCOH is not possible without the teamwork, dedication, and hundreds of combined hours of work each year provided by the executive team.

\section{Structure of the Conference: Workshops, Seminars, Keynote Speakers}

The $\mathrm{CUCOH}$ delegate experience aims to connect undergraduate students with speakers with diverse backgrounds in healthcare while giving them hands-on experience through innovative workshops and allowing them to apply their knowledge and work with each other during engaging case challenges. Typically, there are 3-5 keynote speakers that every delegate attends and a wide variety of workshops and seminars that can be selected based on interest during registration.

The keynote speakers are selected based on the conference's theme during that given year and are typically where the majority of expenses related to the speaker's committee portfolio are generated. Keynotes often cover more controversial topics, giving an account of their own experiences within interdisciplinary healthcare and focus on inspiring delegates to bring fresh perspectives and passion into whichever field they ultimately pursue. Seminars are conducted by experts in more focused areas of healthcare, often research-based, and provide small but comprehensive glimpses into their area of expertise. These seminar speakers often are also offered the opportunity to conduct one of the case challenges.

Each year delegates are split into $6+$ case challenge groups where they are given background on a specific controversial topic in interdisciplinary healthcare. Within their 6 groups, they are split into smaller teams and given the opportunity to prepare a presentation on their proposed solution to the given problem in front of their peers and expert judges. Prizes are then awarded to the winner within each of the topic groups. This provides delegates with the opportunity to practice presenting while familiarizing themselves with important topics in healthcare today, working as collaborators with other passionate delegates. To provide a break from speakers and seminars, as well as to give valuable hands-on experience to $\mathrm{CUCOH}$ delegates, workshops are run concurrently with seminars throughout the conference weekend. There are a few workshops that are run annually (i.e. suturing, laparoscopic surgery, and anatomy lab) as well as new workshops added every year to ensure that there are options for returning delegates.

\section{CUCOH Conference Planning Timeline}

When thinking about planning, it is important to always consider more time for your planning team than initially anticipated. Our planning process for the November conference typically starts in February of that year at the latest ( 8 months in advance). We start by hiring our Executive team and transitioning them with the outgoing team in late February/early March. We then immediately select the conference weekend and book all of the spaces at Queen's University and externally that we will be using: major conference center, breakout rooms, speciality lab spaces, banquet hall, hotels, and clinical training spaces. We then advertise the "save the date" to our external ambassadors and university institution partnerships. This also aids to coordinate with other healthcare conferences locally to space out conferences for delegates to avoid delegate fatigue. This process should be complete by mid-March.

Throughout the summer months, that majority the planning takes place: promoting the research competition and lining up judges, booking speakers and workshop leaders, coordinating case challenges, seeking sponsorship and grant funding, and organizing logistics. This planning peri- 
UNDERGRADUATE RESEARCH IN NATURAL AND CLINICAL SCIENCE AND TECHNOLOGY (URNCST) JOURNAL Read more URNCST Journal articles and submit your own today at: https://www.urncst.com

od is the most important to set reasonable timelines. Delegate tasks within each committee, so that your team is just finalizing details and executing the plan the two months leading up to the conference. Your focus at this point should be on promoting the conference within your university connections.

The final two months before the conference the conference is advertised both at Queen's and externally through our marketing team and external ambassadors. The registration system is launched by Web/IT and all tickets are sold at the latest 1 month before the conference. In the month leading up to the conference delegate and speaker numbers are finalized with hotels and any last minute decorations and supplies are purchased.

Leading up to the conference weekend, a contingency meeting is held all members of the Executive Team as well as volunteers are given their weekend schedule that has been determined by the logistics team. Tasks include conference set-up/take-down, monitoring registration, mealtime set-up/take-down and monitoring, coat check, and ushering delegates to their next event. The speakers team meets all speakers and workshop facilitators as they arrive and makes sure that their presentations are ready to go, Web/IT managers registration, and photography documents the conference.

After the conference ends, post-conference surveys are sent to delegates and the Executive Team has a wrap-up meeting to discuss the positive points of the conference weekend and what might need improving. Finally, a new Chair/Co-Chairs are hired by the outgoing Chair/Co-Chairs and they go on to hire the new executive team.

\section{CUCOH Research Competition}

At its yearly conference, CUCOH offers a Research Competition to showcase the innovation and efforts of delegates. The Research Competition is comprised of an oral competition and a poster competition, with categories in the Biomedical Sciences and Social Sciences, to cover the breadth of research within interdisciplinary healthcare. In its inaugural years, the Research Competition was a oneday event during the final day of CUCOH's, with approximately $12-16$ oral research projects selected to participate in the oral competition and 30-40 posters selected in the poster competition. The oral competition would take place in four seminar rooms, during a one-hour period in the morning of the last day of the conference, allowing for 4 presentations per seminar room. The poster competition would take place during the lunch-hour following the oral competition on the same day.

Recently, in 2017, the Research Competition grew significantly to offer a two-day competition. Akin to graduate and professional-level conference models, this change allowed for more oral and poster presentations to be accepted, integrating student research throughout the entire duration of the conference. In 2017, the conference accepted 20 oral research projects, creating 5 unique presentation rooms with the following themes: "Biochemistry \& Applications", "Molecular Biology", "Oncology", "Physiology", and "Social Sciences", accounting for the diverse of abstracts received. This model also allowed the poster competition to be split over two days' lunch hours, with 25 posters accepted per day (50 total).

Presentations in both competitions were assessed by a panel of judges, consisting of professors, graduate students, and healthcare professionals from diverse research backgrounds. Judges were matched for expertise in the presentations they assessed (ex. MSc candidate in Biochemistry assessed Biochemistry oral and post presentations). Feedback would be provided to the student researchers to encourage further development of research presentation skills. A first, second, and third place winner for each competition is determined by judges' feedback, and monetary prizes is awarded at the end of the conference during an awards ceremony. Additionally, a "People's Choice Award" for the poster competition is also awarded.

Finally, the $\mathrm{CUCOH}$ research team felt it important for students to gain professional recognition for their presentation at the competition. In 2017, CUCOH collaborated with the Undergraduate Research in Natural and Clinical Science and Technology (URNCST) Journal to publish the abstracts of this year's conference. Students were overwhelmingly in support of this partnership, as it offered recognition for the work of student researchers and will hopefully aid in the expansion of the conference in the years to come. $\mathrm{CUCOH}$ hopes that the changes in structure and partnerships formed this year will aid in setting the foundation for further growth of the Research Competition.

\section{Successes and Challenges of CUCOH in the Last Decade} Successes

1) Over the past 13 years, $\mathrm{CUCOH}$ has gone from a conference with dozens of delegates and a budget in the low hundreds to a conference boasting over 400 delegates and over a $\$ 50,000$ budget. This is largely attributed to increased sponsorship associated with corporate engagement due to student interest as well as an increase in conference ticket prices as the quality of the conference provided improved annually.

2) The reach of $\mathrm{CUCOH}$ has now exceeded just Canadian interest. This past year, undergraduate students reached out from the United States and Pakistan. This speaks to promising opportunity for expansion. Currently $\mathrm{CUCOH}$ is delighted to welcome students from 24 universities and 8 provinces annually, displaying incredible growth from the initial conference that was held for Queen's University students.

3) While hundreds of Canadian undergraduate conferences exist, $\mathrm{CUCOH}$ partially attributes its success to its focus on preparing students for conferences at the graduate and professional level. The unique combination of networking opportunities and a research component to practice presentation skills are invaluable to 
undergraduate students interested in pursuing research or business in healthcare.

4) A common complaint of students interested in healthcare is that many undergraduate conferences and events place a focus on preparation for applying to medical school, post-graduation. CUCOH prides itself in the diversity and interdisciplinary nature of how healthcare is discussed. Not only does this expose students to career opportunities they may have never even been aware of previously, it paints a more realistic picture of Canadian healthcare.

\section{Challenges}

1) Despite the unique overlap of experiences offered at $\mathrm{CUCOH}$, there remains a continuous challenge to differentiate this conference from the dozens of other healthcare conferences available to undergraduate students.

2) Managing hundreds of individuals poses a significant challenge, especially when more than 250 of them have traveled from out of town. While the CUCOH team does their best to accommodate all dietary restrictions, individual preferences, and accommodation specifications, it is inevitable that mistakes or miscommunications will occur during the execution of such a largescale conference.

3) A large-scale multifaceted conference requires a large team with many specialized roles throughout the planning process. The challenge of having such a large team is developing effective communication channels to ensure that everyone understands not only their own roles but has enough of an understand of the other portfolios to work as collaborators and be able to step in to assist other executive members.

\section{Advice to Future Conference Developers}

As a conference team, we have learned a lot from our successes and challenges over the years. In reflection, we will leave you with six core pieces of advice when developing your future conference:

1) Choose a team that is strong in the four core domains of conference planning: project management and logistics, finances and sponsorship, marketing and promotions, and seminar and workshop program development. Creating a strong, enthusiastically invested team is the number one step in conference success. Also, we encourage having leaders from a variety of years and disciplines, in addition to including first- and secondyear interns, to encourage sustainability, longevity, and growth of your leadership team.

2) If you intend to have a Research Competition, we would strongly encourage involvement of graduate research students and even consultation and supervision from Faculty who has had experience in running research competitions at the graduate-level. Their experi- ence will be invaluable as you create and manage your competition.

3) On a similar point, our Research Competition saw incredible success in 2017 with the establishment of publishing abstracts with URNCST. This provides a platform to publish our research delegate's work, oftentimes for their first time, and provides a legacy for conference planners. We highly encourage seeking an opportunity to publish conference abstracts with URNCST.

4) Start small. One of the number one lessons we learned in growing our conference was the need to start with a small conference and focus on sustainable growth. This allows for focus on 1-2 core growth areas (ex. expanding workshops, adding more speakers, growing a Research competition, etc.) annually, without demanding too much of your team, breaking the budget, or losing quality on the initial core aspects of your conference. Slow and steady in growth allows for long-term success and sustainability, year-to-year.

5) Leverage eagerness of undergraduate students at other institutions to encourage participation and growth of the conference, if you intend to go province- or nationwide. $\mathrm{CUCOH}$ has delegate representatives from major Canadian undergraduate universities, allowing for large-scale logistics coordination (ex. booking transportation to the conference as a group), targeted marketing of the conference and Research competition, and adding valuable voices to improving the conference to better meet the needs of each partner university institution.

6) Have fun, learn from each other, and roll with the challenges - because they will inevitably come! Some of our best moments of our Undergraduate careers have been during our time with $\mathrm{CUCOH}$ - particularly when working through the challenges of putting on a largescale conference. Take time to laugh and appreciate each other's strengths and what they bring to your team.

In conclusion, we hope that you have found this article informative for you and your conference planning group, and we wish you the absolute best in your planning.

For more information about $\mathrm{CUCOH}$, attending or presenting at the conference, please see the links below:

Website: https://www.cucoh.com/

Facebook: https://www.facebook.com/CUCOHQueensU

Also, feel free to connect with the corresponding authors by email if you have any questions regarding the article and conference planning. 
UNDERGRADUATE RESEARCH IN NATURAL AND CLINICAL SCIENCE AND TECHNOLOGY (URNCST) JOURNAL Read more URNCST Journal articles and submit your own today at: https://www.urncst.com

\section{List of Abbreviations}

CUCOH: Canadian Undergraduate Conference on

Healthcare

URNCST: Undergraduate Research in Natural and Clinical

Science and Technology

\section{Conflicts of Interest}

The author(s) declare that they have no conflicts of interest.

\section{Acknowledgements}

The authors wish to acknowledge the incredible work the last fourteen Executive teams have done to contribute to $\mathrm{CUCOH}$, and the work of many more teams to come. We would also like to thank the Editor, Jeremy $\mathrm{Ng}$, for his ongoing support for $\mathrm{CUCOH}$ and the development of this editorial.

\section{Authors' Contributions}

KL and JSW contributed equally to the development and editing of the editorial, based on their experience with $\mathrm{CUCOH}$.

\section{Article Information}

Managing Editor: Jeremy Y. Ng

Article Dates: Received Apr 23 18; Accepted May 07 18; Published May 2318

\section{Citation}

Please cite this article as follows:

Liblik K, Williams JS. 14 years of progress: Canadian undergraduate conference on healthcare. URNCST Journal. 2018 May 23: 2(5). https://urncst.com/index.php/urncst/article/view/52

DOI Link: https://doi.org/10.26685/urncst.52

\section{Copyright}

(C) Kiera Liblik, Jennifer S. Williams. (2018). Published first in the Undergraduate Research in Natural and Clinical Science and Technology (URNCST) Journal. This is an open access article distributed under the terms of the Creative Commons Attribution License (https://creativecommons.org/licenses/by/4.0/), which permits unrestricted use, distribution, and reproduction in any medium, provided the original work, first published in the Undergraduate Research in Natural and Clinical Science and Technology (URNCST) Journal, is properly cited. The complete bibliographic information, a link to the original publication on http://www.urncst.com, as well as this copyright and license must be included.
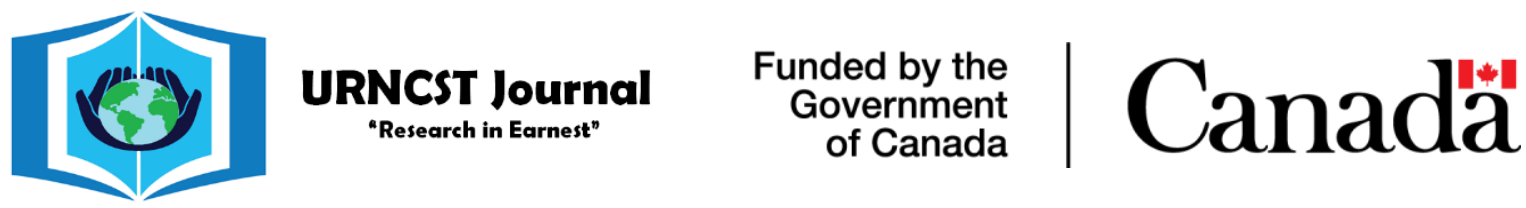

Do you research in earnest? Submit your next undergraduate research article to the URNCST Journal! | Open Access | Peer-Reviewed | Rapid Turnaround Time | International | | Broad and Multidisciplinary | Indexed | Innovative | Social Media Promoted | Pre-submission inquiries? Send us an email at info@urncst.com | Facebook, Twitter and LinkedIn: @URNCST Submit YOUR manuscript today at https://www.urncst.com! 